\title{
Active transcription and ultrastructural changes during Trypanosoma cruzi metacyclogenesis
}

\author{
LUDMILA R.P. FERREIRA ${ }^{1}$, FERNANDO DE M. DOSSIN ${ }^{1}$, THIAGO C. RAMOS ${ }^{1}$, \\ EDNA FREYMÜLLER ${ }^{2}$ and SERGIO SCHENKMAN ${ }^{1}$ \\ ${ }^{1}$ Departamento de Microbiologia, Imunologia e Parasitologia, Universidade Federal de São Paulo, \\ Rua Botucatu, 862, $8^{\circ}$ andar, Vila Clementino, 04023-062 São Paulo, SP, Brasil \\ ${ }^{2}$ Centro de Microscopia Eletrônica, Universidade Federal de São Paulo, Edifício de Ciências Biomédicas \\ Rua Botucatu, 862, térreo, Vila Clementino, 04023-062 São Paulo, SP, Brasil
}

Manuscript received on November 23, 2007; accepted for publication on January 21, 2008; contributed by SERGIO SCHENKMAN*

\begin{abstract}
The differentiation of proliferating epimastigote forms of Trypanosoma cruzi, the protozoan parasite that causes Chagas' disease, into the infective and non-proliferating metacyclic forms can be reproduced in the laboratory by incubating the cells in a chemically-defined medium that mimics the urine of the insect vector. Epimastigotes have a spherical nucleus, a flagellum protruding from the middle of the protozoan cell, and a disk-shaped kinetoplast - an organelle that corresponds to the mitochondrial DNA. Metacyclic trypomastigotes have an elongated shape with the flagellum protruding from the posterior portion of the cell and associated with a spherical kinetoplast. Here we describe the morphological events of this transformation and characterize a novel intermediate stage by three-dimensional reconstruction of electron microscope serial sections. This new intermediate stage is characterized by a kinetoplast compressing an already elongated nucleus, indicating that metacyclogenesis involves active movements of the flagellar structure relative to the cell body. As transcription occurs more intensely in proliferating epimastigotes than in metacyclics, we also examined the presence of RNA polymerase II and measured transcriptional activity during the differentiation process. Both the presence of the enzyme and transcriptional activity remain unchanged during all steps of metacyclogenesis. RNA polymerase II levels and transcriptional activity only decrease after metacyclics are formed. We suggest that transcription is required during the epimastigote-to-metacyclic trypomastigote differentiation process, until the kinetoplast and flagellum reach the posterior position of the parasites in the infective form.
\end{abstract}

Key words: Trypanosoma cruzi, metacyclogenesis, transcription, RNA polymerase II.

\section{INTRODUCTION}

The differentiation of epimastigotes into metacyclic trypomastigotes (metacyclics), called metacyclogenesis, is a fundamental step in the life cycle of T. cruzi, the etiological agent of Chagas' disease. This process occurs at the terminal portion of the triatomine hindgut, where elongated epimastigotes attach prior to differentiating into metacyclic forms (Kollien and Schaub 2000). Once

\footnotetext{
*Member Academia Brasileira de Ciências

Correspondence to: Sergio Schenkman

E-mail: sschenkman@unifesp.br
}

formed, metacyclics detach from the hindgut wall and are excreted. Infection is mediated through the contact of these excreta with mucous membranes of a mammalian host. It is not clear how the differentiation process is triggered, but it has been demonstrated that metacyclogenesis is induced by a nutritional stress that happens in the insect's gut environment (Contreras et al. 1988, Figueiredo et al. 2000, Wainszelbaum et al. 2003). Since the establishment of Contreras' triatomine artificial urine (TAU) medium, a chemically-defined medium that mimics the 
composition of the insect's urine, this process can be reproduced in vitro. Metacyclogenesis is induced, in vitro, by incubating epimastigote forms in TAU medium and, subsequently, in TAU supplemented with amino acids and glucose (TAU3AAG medium). Under these conditions, parasites adhere to the flask and undergo differentiation (Bonaldo et al. 1988). In vitro metacyclogenesis makes synchronization of the cells possible; hence parasites at different stages of the differentiation process can be isolated from the culture and their biological features studied. Several major phenotypic changes occur during metacyclogenesis, including non-proliferation and the development of infectivity with changes in the cell morphology. In addition, nuclear structure modifications (Elias et al. 2007), chromatin remodeling, and differential mRNA stability (Krieger and Goldenberg 1998, Yamada-Ogatta et al. 2004), result in differences of protein expression (Parodi-Talice et al. 2007) during metacyclogenesis.

Gene expression in T. cruzi is controlled post-transcriptionally. Genes are transcribed polycistronically and subsequently cleaved into functional mRNAs, requiring trans-splicing of a capped 39-nucleotide leader RNA derived from a short transcript, the spliced leader (SL) RNA (Teixeira 1998). As described previously T. cruzi RNA polymerase II (RNA Pol II) is found concentrated in a domain close to the parasite nucleolus, which represents actively transcribed spliced leader genes (Dossin and Schenkman 2005). The remaining RNA Pol II is distributed in several foci in the nucleoplasm. In trypomastigote stages, transcription is diminished (Elias et al. 2001) with dispersal of the major RNA Pol II foci (Dossin and Schenkman 2005). In the present work we asked when, during metacyclogenesis, the transcriptional activity decreases and RNA Pol II foci disperse. We also describe the morphological events that include the repositioning of the flagellum and the kinetoplast in the parasite cell body and characterize the intermediate form at the ultrastructure level. We found that transcriptional activity is constant and RNA Pol II distribution is maintained in the nucleus during the entire metacyclogenesis process, disassembling only when the metacyclic-trypomastigotes are formed, implying that transcriptional activity is required to complete metacyclogenesis.

\section{MATERIALS AND METHODS}

\section{PARASITES AND IN VITRO METACYCLOGENESIS}

The T. cruzi Dm28c clone was obtained and cultured in the laboratory in liver infusion tryptose (LIT) medium, containing $10 \%$ fetal bovine serum at $28^{\circ} \mathrm{C}$ (Contreras et al. 1988). To induce metacyclogenesis we followed the procedure described by (Contreras et al. 1988, Figueiredo et al. 2000). Briefly, epimastigotes were grown to stationary phase $\left(5 \times 10^{7}\right.$ cells $\left./ \mathrm{mL}\right)$, collected by centrifugation at $2000 \mathrm{~g}$ for 15 minutes at $10^{\circ} \mathrm{C}$, and resuspended to $5 \times 10^{8}$ cells $/ \mathrm{mL}$ in TAU medium $(190 \mathrm{mM}$ $\mathrm{NaCl}, 17 \mathrm{mM} \mathrm{KCl}, 2 \mathrm{mM} \mathrm{MgCl} 2,2 \mathrm{mM} \mathrm{CaCl}_{2}, 8 \mathrm{mM}$ sodium phosphate buffer, $\mathrm{pH} 6.0$ ). After 2 hours at $37^{\circ} \mathrm{C}$, parasites were diluted 100 fold in TAU supplemented with $50 \mathrm{mM}$ sodium glutamate, $10 \mathrm{mM}$ L-proline, $2 \mathrm{mM}$ sodium aspartate, and $10 \mathrm{mM}$ glucose, allowed to attach to culture flasks and maintained afterwards at $28^{\circ} \mathrm{C}$. Attached parasites were collected 24, 48 and 72 hours later by removing the supernatant and vigorously shaking the parasites with supplemented TAU medium. Metacyclic trypomastigotes were obtained from the culture supernatants after 72 hours.

\section{IMMUNOFLUORESCENCE ANALYSIS}

Immunofluorescence experiments were done with parasites attached to glass slides pretreated with $0.01 \%$ polyL-lysine. Alternatively, the differentiation process was conducted in 24 well plates containing $12 \mathrm{~mm}$ glass coverslips. Attached parasites were fixed with 0.5 to $4 \%$ paraformaldehyde at $4{ }^{\circ} \mathrm{C}$ for 15 minutes and permeabilized in phosphate-buffered saline (PBS) containing $0.1 \%$ Triton X-100. The fixed and permeabilized cells were washed with PBS, and the slides, or coverslips, were incubated with the primary antibody for 1 hour at room temperature. Antibodies to T. cruzi RNA-Pol II were obtained from rabbits immunized with a recombinant carboxy-terminal fragment unique to T. cruzi RNAPol II as described previously (Dossin and Schenkman 2005). Monoclonal antibody 25 (mAb 25), which is specific for the flagellar calcium-binding protein (Elias et al. 2007), was used to highlight flagellar structures. The preparations were washed with PBS, incubated with anti-rabbit, or anti-mouse $\mathrm{IgG}$, conjugated respectively to rhodamine or fluorescein (Santa Cruz Biotechnology, Santa Cruz, CA), and mounted in VectaShield (Vector 
Laboratories) in the presence of $10 \mu \mathrm{g}$ of 4'6'diamidino2-phenylindole (DAPI) per mL.

\section{SCANNING ELECTRON Microscopy}

Parasites were fixed with $2.5 \%$ glutaraldehyde, $2 \%$ formaldehyde in $0.1 \mathrm{M}$ cacodylate buffer $\mathrm{pH} 7.2$, for 1 hour at room temperature under constant agitation. The fixed parasites were then decanted overnight on glass coverslips precoated with $0.01 \%$ poly-L-lysine. The coverslips were washed three times with $0.1 \mathrm{M}$ cacodylate pH 7.2 (10 minutes each) and then incubated with $1 \%$ osmium tetroxide in the same buffer for 30 minutes at room temperature, washed with cacodylate buffer, and treated for 30 minutes with $1 \%$ tannic acid solution. After this treatment coverslips were washed twice in distilled water (10 minutes each) and impregnated once more with $1 \%$ osmium tetroxide (30 minutes), gradually dehydrated in ethanol solutions (70, 90 and 100\%), and dried in a Balzers CPD 030 apparatus. The slides were mounted, gold coated in a Balzers SCD 050, and examined in a Scanning Electron Microscope JEOL 5300.

\section{Transmission ELECTRON Microscopy}

Parasites were fixed for 2 hours at room temperature with $2 \%$ formaldehyde, $2.5 \%$ glutaraldehyde in $0.1 \mathrm{M}$ sodium cacodylate buffer at $\mathrm{pH}$ 7.2. Ultrathin serial longitudinal sections were obtained as described (Alberio et al. 2004), by processing fixed parasites attached to plastic coverslips precoated with $0.01 \%$ poly-L-lysine as described above for scanning electron microscopy. Parasites on the coverslips were then post-fixed with $1 \%$ osmium tetroxide in the same buffer for 30 minutes at room temperature, washed with cacodylate buffer, gradually dehydrated in a series of ethanol solutions, and embedded in Epon resin. After sectioning to produce consecutive sections the material was stained with uranyl acetate and lead citrate, mounted on Formvar grids, and observed in a JEOL 1200 EX II transmission electron microscope at $80 \mathrm{kV}$.

\section{THREE-DIMENSIONAL RECONSTRUCTIONS}

Three-dimensional reconstruction was made with images obtained with a CCD camera attached to the microscope. The images were aligned using the Reconstruct ${ }^{\circledR}$ (version 1.0.9.6) software (Fiala 2005) in the linear mode by selecting congruent points in alternate images. After alignment, the morphological structures were manually traced using the Draw Closed Point by Point function, and the three-dimensional images generated by the program.

\section{TRANSCRIPTION ASSAY}

Transcription assays were performed with $2 \times 10^{8}$ lysed parasites per time point. Parasites were harvested at different time points of metacyclogenesis. The adherent parasites ( 24 and 48 hours) were harvested by gentle cell scraping. The parasites were centrifuged at $2000 \mathrm{~g}$ for 10 minutes and washed twice in transcription buffer (150 $\mathrm{mM}$ sucrose, $20 \mathrm{mM}$ potassium glutamate, $3 \mathrm{mM}$ $\mathrm{MgCl}_{2}, 3 \mathrm{mM}$ DTT and $10 \mathrm{~g} / \mathrm{mL}$ leupeptin). Nuclei were isolated in transcription buffer containing $0.5 \%$ of Nonidet P40, centrifuged at $10000 \mathrm{~g}$ for 3 minutes, and washed twice in transcription buffer to remove the residual detergent. Labeling reactions were done in transcription buffer containing $100 \mathrm{mCi}$ of $\left[\alpha^{32} \mathrm{P}\right]-\mathrm{UTP}$ (3000 Ci/mmol, Dupont) per $2 \times 10^{8}$ parasites, $4 \mathrm{mM}$ of ATP, CTP, GTP (Roche), $200 \mu \mathrm{g}$ of creatine kinase per $\mathrm{mL}, 50 \mathrm{mM}$ creatine phosphate for 15 minutes at $30^{\circ} \mathrm{C}$. Nascent radio-labeled RNA was extracted using Trizol (Invitrogen) and incorporation was measured by liquid scintillation counting.

\section{RESULTS}

Morphological Alterations and Repositioning of the Nucleus, Flagellum and Kinetoplast During DIFFERENTIATION

Induction of metacyclogenesis occurs after starving the parasites in TAU medium and diluting the parasites in the same medium additionally containing glucose and the amino acids proline, aspartate and glutamate (Bonaldo et al. 1988). Within twenty fours after induction, almost all parasites attach to the cell culture flask and conserve the morphology of epimastigotes. Indirect immunofluorescence using an antibody against the flagellum and DAPI (to highlight the nucleus and kinetoplast) allowed us to see details of the progress of T. cruzi differentiation (Fig. 1). The epimastigote forms have a spherical nucleus with a flagellum protruding from the anterior portion of the cell body near the disk-shaped kinetoplast (top panel, Fig. 1). Forty-eight hours after the induction, an increased number of intermediate forms, but not try- 
pomastigotes, could be detected. These forms consisted of parasites with kinetoplast superimposing an elongated nucleus. In some parasites the kinetoplast was anterior, in others at the middle, and in others posterior in relation to the elongated nucleus. The anterior part of the parasite is defined by the direction of epimastigote swimming, which is towards the flagellum protrusion of the epimastigote. At longer incubation periods, increasing numbers of metacyclic trypomastigotes were found in the cell culture supernatant. Metacyclic forms have a fully elongated nucleus with a round kinetoplast at the posterior portion end of the parasite (Fig. 1, bottom panel).

Based on their morphology we divided the intermediate forms that occur during metacyclogenesis into three stages: Ia, Ib and Ic as shown in Figure 2A. The percentage of each intermediate stage was quantified along the differentiation time. At 24 hours after induction of differentiation, about $40 \%$ of the parasites were at stage Ia and very few at stages Ib and Ic (Fig. 2B). At 48 hours, a larger proportion amount of parasites were at stages $\mathrm{Ib}$ and Ic, but almost one half of the attached parasites were similar to epimastigotes and the other half in stage Ia. At 72 hours, a large percentage number of parasites detach from the substrate, most of them as metacyclic trypomastigotes.

RNA POL II LABELING AND TRANSCRIPTIONAL ACTIVITY IS ONLY REDUCED IN COMPLETELY DIFFERENTIATED CELLS

As described earlier, the RNA polymerase II (RNA Pol II) of exponentially growing epimastigotes is concentrated in the nuclear interior in a region that correspond to the active transcription of spliced leader genes (Dossin and Schenkman 2005). When transcription diminishes in the infective trypomastigote forms derived from infected mammalian cells (Elias et al. 2001), the RNA Pol II labeling decreases (Dossin and Schenkman 2005). By using the same antibody, directed to the carboxyterminal domain of RNA Pol II it was evident that a similar RNA Pol II labeling was obtained in parasites before metacyclogenesis induction, and in all intermediate stages (see green spots in Fig. 2A). The labeled major spot only disappears in fully differentiated metacyclic forms.

To confirm that transcription decreases only in meta- cyclic trypomastigotes, cells were treated with detergent to isolate nuclei and probed by incorporation of radiolabeled $\left[\alpha^{32} \mathrm{P}\right]-\mathrm{UTP}$ at conditions optimized for RNA Pol II labeling (Ullu and Tschudi 1990, Elias et al. 2001). Radiolabeled nascent RNA was isolated and quantified by liquid scintillation counting. The percentage of incorporation relative to epimastigotes was calculated based on three independent experiments and revealed that transcriptional activity was also maintained during metacyclogenesis, declining only after 72 hours, when most of the parasites had completed metacyclogenesis (Fig. 3).

\section{ULTRASTRUCTURE CHARACTERIZATION OF}

INTERMEDIATE FORMS REVEALS AN ACTIVE RE-

LOCATION OF THE KinETOPLAST AND THE FLAGELLUM

Changes in T. cruzi morphology during metacyclogenesis were visualized by transmission and scanning electron microscopy. As illustrated in Figure 4, epimastigotes present a typical disk-shaped kinetoplast $(\mathrm{k})$ located between the nucleus (n) (panel A) and the flagellum (f) (panel B). The cell can be divided in two portions; the anterior, which is linked to the flagellum, and the posterior, a more enlarged and conical form. In dividing cells, a new flagellum is seen exiting the small aperture of the flagellar pocket (see arrow in panel B). Intermediate forms, collected 48 hours after induction of metacyclogenesis, show the kinetoplast between two portions of the nucleus (panel $\mathrm{C}$ ), and the flagellum protruding from a larger orifice overture of the flagellar pocket between two more similar portions of the cell body (panel D). Scanning electron microscopy images also show that intermediate forms have pronounced body torsion. Metacyclic-trypomastigotes typically have a very elongated nucleus and a circular-shaped kinetoplast at the posterior of the cell body (panel E). The flagellum is connected to the entire length of the cell body (panels E and F).

To further understand how the transition occurs, longitudinal serial sections of intermediate forms as shown in Figure 4 and attached to a coverslip, were photographed (Fig. 5A) and the images used to reconstruct three-dimensional representations of the parasite. As shown in Figure 5B and in more detail in Figure 5C, the disk-shaped kinetoplast (yellow), still associated with the flagellum (red), is compressed against the cell nucleus (cyan). The nucleus, containing the nucleolus 


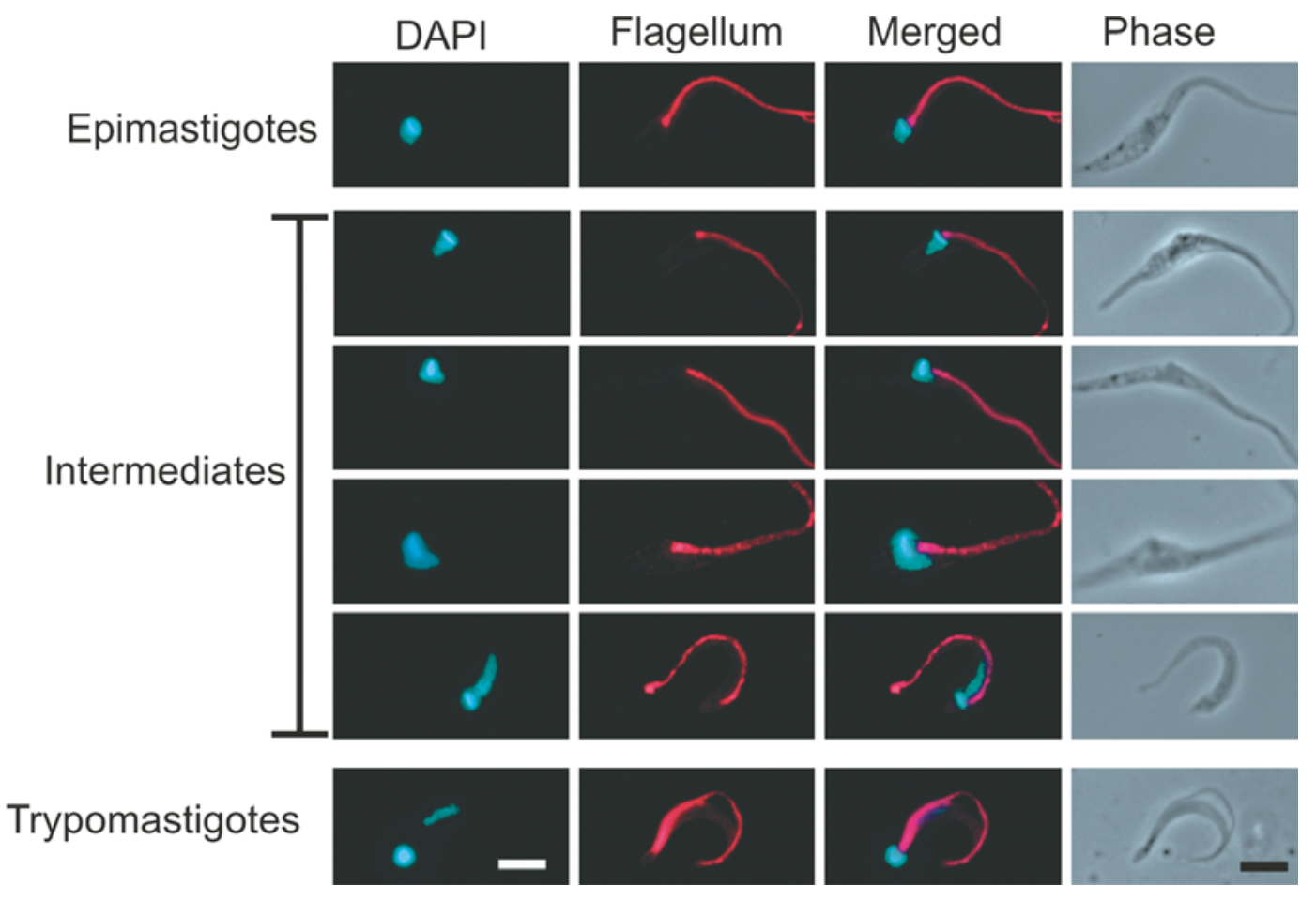

Fig. 1 - Visualization of the metacyclogenesis process. Stationary growing T. cruzi (DM28c strain) epimastigotes were incubated in TAU medium at $28^{\circ} \mathrm{C}$ at the concentration of $5 \times 10^{8}$ parasites per mL. After 2 hours, the cells were diluted in TAU3AAG medium to a concentration of $5 \times 10^{6}$ parasites per $\mathrm{mL}$ and plated on tissue culture flasks. Parasites were harvest at different time points during the metacyclogenesis process and attached to glass slides pretreated with $0.01 \%$ poly-L-lysine. Attached parasites were fixed with $4 \%$ paraformaldehyde in PBS and permeabilized with $0.1 \%$ Triton X100 before DAPI (left column) and indirect immunofluorescence reactions using $\mathrm{mAb} 25$ (anti-flagellum, middle column). The figure also shows the merged fluorescent images, and the phase contrast of the same field (right column). Bars $=3 \mu \mathrm{m}$.

(violet) appears to be distorted by unknown forces or intracellular structures.

\section{DISCUSSION}

We have characterized some morphological events occurring when T. cruzi epimastigotes transform into metacyclic trypomastigotes, particularly the repositioning of the mitochondrial kinetoplast relative to the cell nucleus. While in epimastigotes the disk-shaped kinetoplast is located between the spherical nucleus and the site of flagellum protrusion, the metacyclic kinetoplast becomes spherical and is located at the opposite side of the cell. We found that after stress induction, no significant changes in kinetoplast and flagellum position occur. However, after 24 to 48 hours after stress induction, the kinetoplast, in association with the flagellum, is pro- gressively displaced over the nucleus. At 72 hours, fully differentiated metacyclics appear in the culture. Detailed ultrastructure analysis and three-dimensional reconstruction of the parasite indicates that the kinetoplast and flagellum are compressed against the elongated nucleus, suggesting that active movements force the displacement of them in intermediate forms. As we observed that transcription remains active in these intermediate forms, decreasing significantly only in fully differentiated forms, we suggest that these morphological changes are actively driven and that entire metacyclogenesis process is not caused by a shutdown of parasite metabolism.

The results showing the presence of intense labeling of RNA Pol II in the nucleus of intermediate forms support the notion that differentiating cells are still actively transcribing, as transcription inhibition were show pre- 


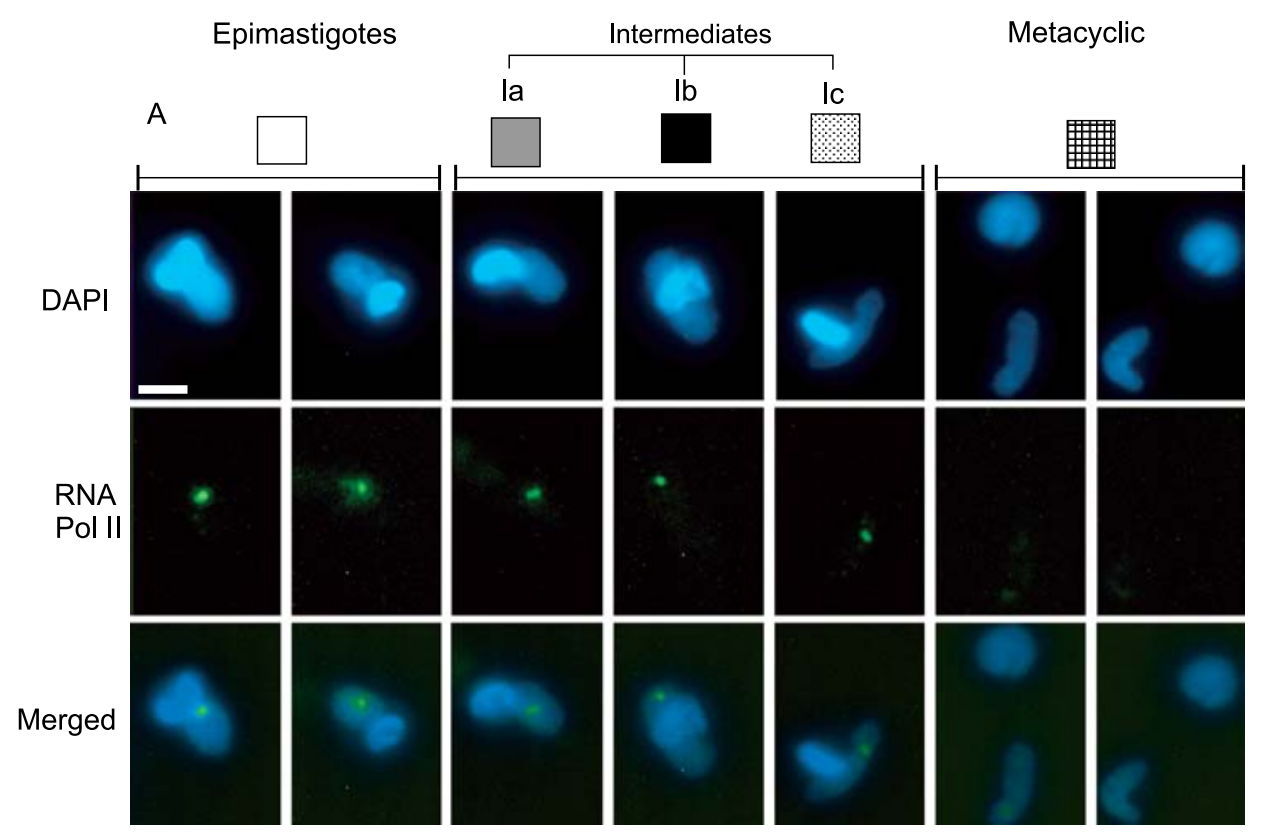

B

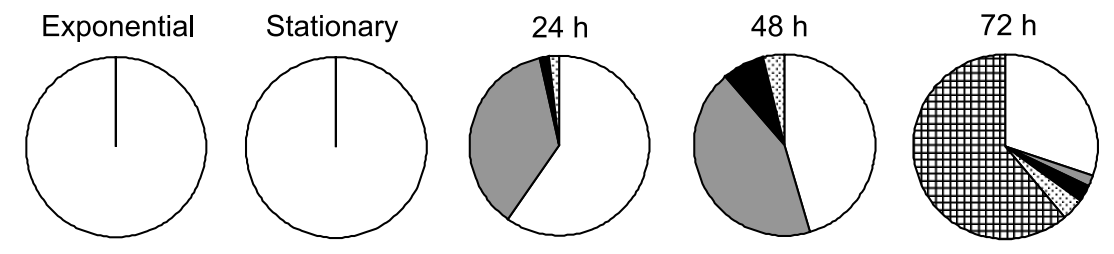

Fig. 2 - RNA Pol II labeling decreases only at the end of metacyclogenesis. A. Parasites at different times after metacyclogenesis were labeled with DAPI and by indirect immunofluorescence using antibodies against the T. cruzi RNA Pol II and DAPI (top and middle images). The bottom figures correspond to merged DAPI and immunofluorescence images. The figure show representative images of epimastigotes, intermediate stages and metacyclic-trypomastigotes. Panel B show the relative number of each parasite form as defined in panel A in exponentially growing cells, at the stationary phase, and 24 and 48 hours after the nutritional stress. The 72 hour graphic indicates the distribution found in the supernatant.

viously to promote its dispersal (Dossin and Schenkman 2005). Indeed, RNA Pol II labeling is completely absent in fully differentiated metacyclics forms, defined as parasite stages with a round kinetoplast and expressing the gp90 antigen (Yoshida et al. 1990). However, the fact that in vitro transcription is largely decreased after 72 hours of stress induction in the total parasite population, which contains around $60 \%$ of fully differentiated metacyclics (in three independent experiments), indicates that transcription is diminished in all stages, even in non-differentiated parasites at 72 hours. Bromouridine triphosphate, a labeled nucleotide used to detected transcription, could be incorporated in permeable epimastigotes and some intermediate forms, but never in metacyclics (data not shown). However, the conditions to obtain permeable metacyclic trypomastigotes were too harsh, destroying all epimastigotes and intermediate forms and making it impossible to precisely 


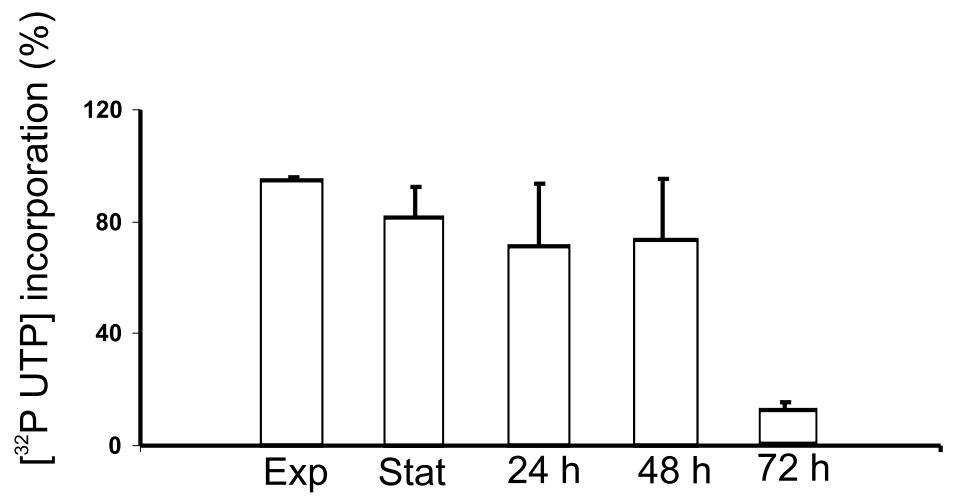

Fig. 3 - Transcription decreases at 72 hours after stress induction. Nuclei were isolated from $2 \times 10^{8}$ parasites per time point, washed twice in transcription buffer and labeled in the presence of $\left[{ }^{32} \mathrm{P}\right]-\mathrm{UTP}$ for 15 minutes at $30^{\circ} \mathrm{C}$. The results are the percentage means of total RNA \pm standard deviation relative to exponentially growing epimastigotes of three independent experiments.

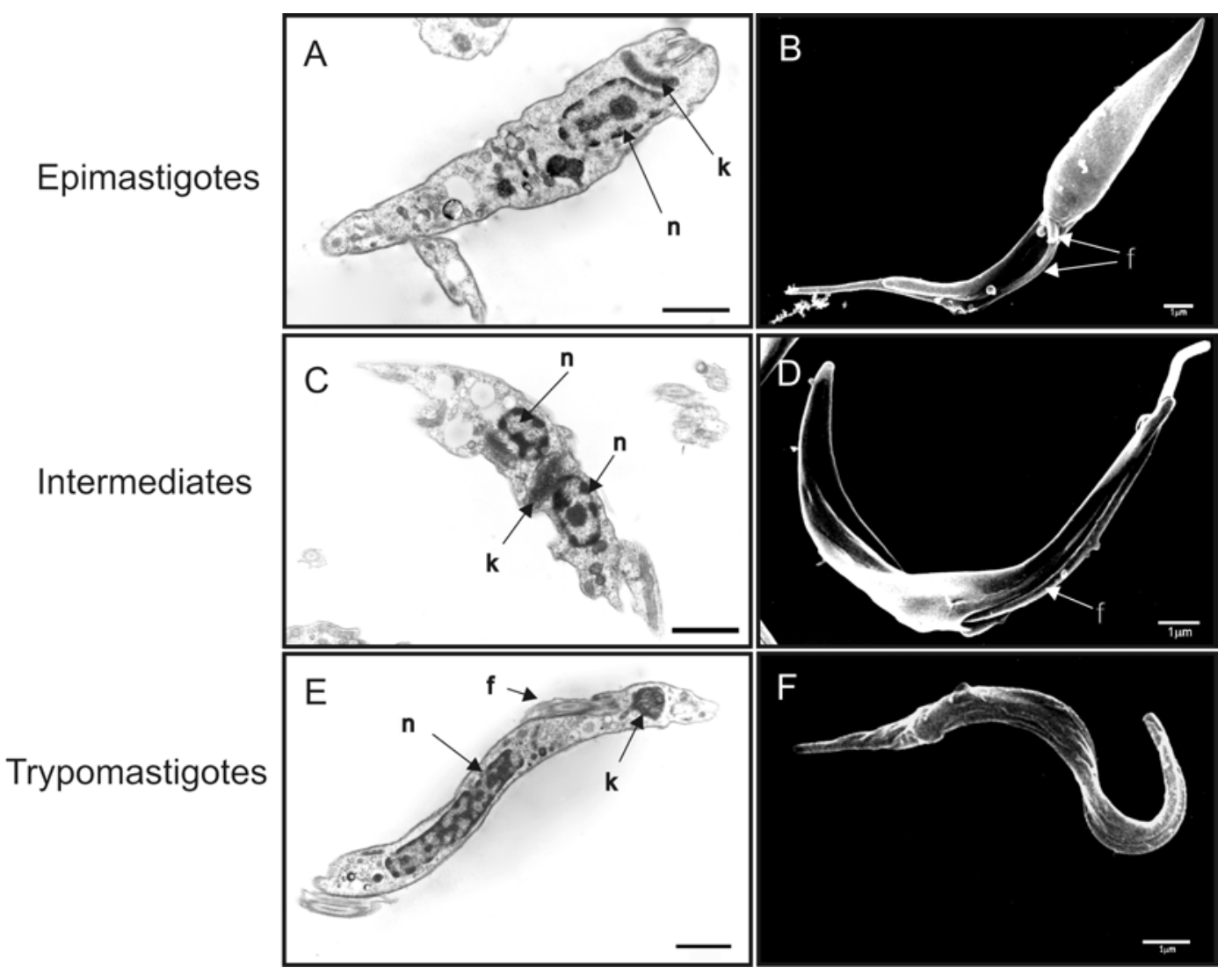

Fig. 4 - Ultrastructure details of epimastigote, intermediate and metacyclic-trypomastigotes. The figure show transmission (left panels) and scanning electron micrographs (right panels) of $T$. cruzi forms obtained during metacyclogenesis. The letters indicate the kinetoplast (k), the nucleus (n) and the flagellum (f). Bars $=1 \mu \mathrm{m}$. 
A
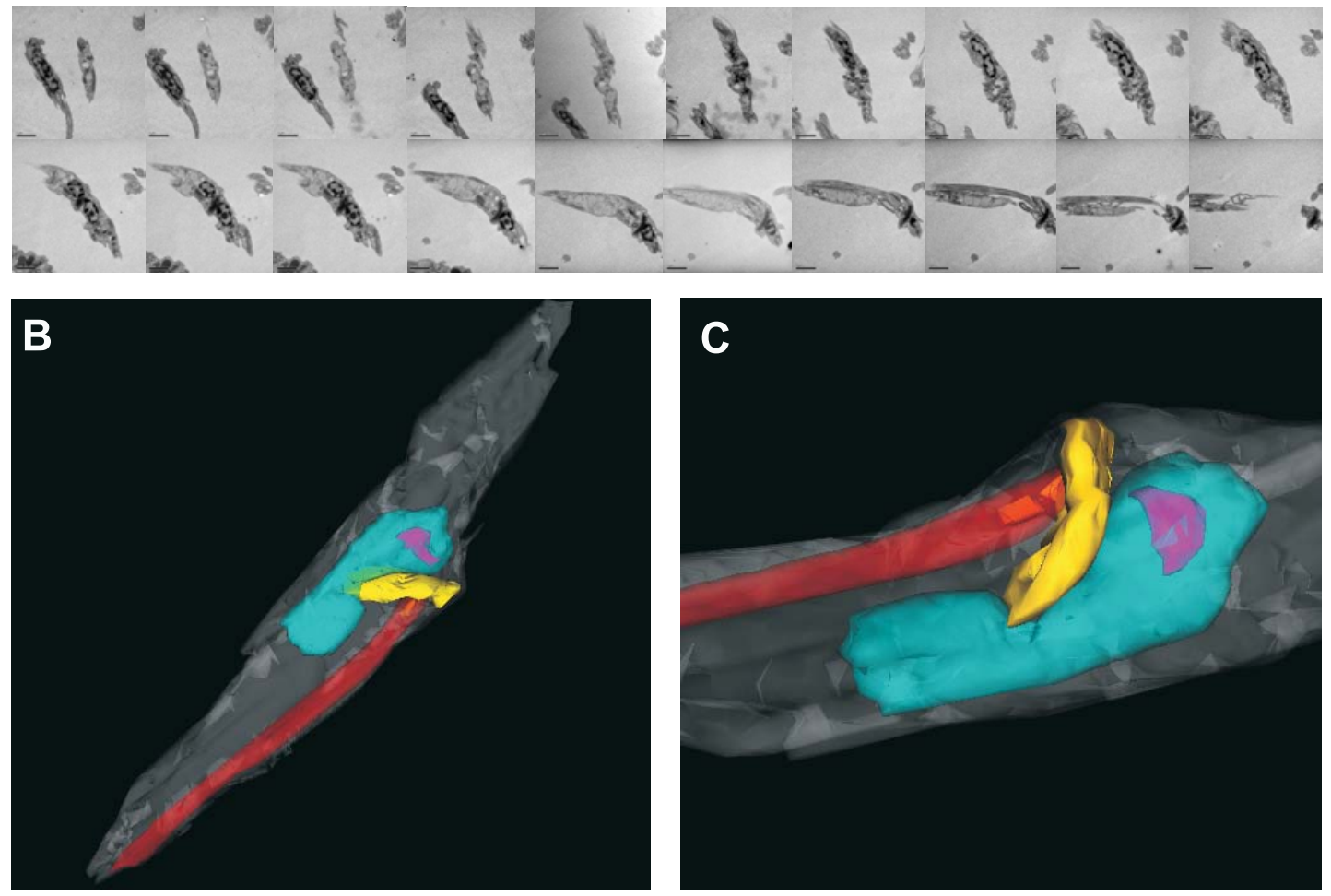

Fig. 5 - Three-dimensional reconstruction of T. cruzi undergoing metacyclogenesis. Panel A shows serial sections of one intermediate stage, isolated 48 hours after stress induction. Panel B and C show cell body (gray), the flagellum (red), the kinetoplast (yellow), the nucleus (blue) and the nucleolus (violet) obtained after three-dimensional reconstruction of the sections shown in A. The cell body, the nucleus and flagellum were made in transparent colors to visualize the internal structures, particularly the base of the flagellum shown in orange.

compare their transcription efficacy in situ. Upon induction of metacyclogenesis, accumulation of mRNA granules is observed (Cassola et al. 2007), with changes in transcript accumulation and protein expression (Krieger et al. 1999). Endocytosis is also diminished (Figueiredo et al. 2000), and the reservosomes, structures that accumulate endocytic products, are gradually degraded (Cunha-e-Silva et al. 2006, Sant'anna et al. 2004), suggesting that a general catabolic process takes place during metacyclogenesis. Thus, our results suggest that although the parasite is reprogrammed to use accumulated nutrients, by changing protein expression, it still requires an active remodeling of its structure. It should be noted that stress induction in Trypanosoma brucei affects spliced leader RNA transcription only after a few days, considered a key factor in promoting a general de- crease in transcription (Lustig et al. 2007).

Conventional electron microscopy analysis illustrates some features of the differentiation process. It is particularly noticeable the conservation of the nuclear structure, with an evident nucleolus and small amounts of condensed chromatin in epimastigotes and intermediate forms, modified in metacyclic forms, compatible with a decreased transcription in this latter form as showed early for tissue culture trypomastigotes (Elias et al. 2001). Nevertheless, the nuclear elongation is seen very early during the differentiation process, indicating that alterations in the nuclear envelope, perhaps on the nuclear lamina components indentified in trypanosomes (Rout and Field 2001), has already taken place prior to differentiation.

It became possible to visualize the cellular organi- 
zation of the intermediate stage only after three-dimensional reconstruction of serial sections of parasites undergoing metacyclogenesis. By serial sectioning parasites (attached on coverslips) longitudinally, we were able to obtain nearly complete cell images necessary for the reconstruction. With this reconstruction, we found the kinetoplast associated with the flagellum closely juxtaposed to the nuclear envelope. A clear deformation of the nucleus can be seen, indicating that either the kinetoplast is pushing backward the nucleus, or that the nucleus is sliding forward.

Alternatively, the sliding forces can be a consequence of $T$. cruzi cytoskeletal contraction and/or reorganization, perhaps with the flagellum pushing the kinetoplast. Metacyclics are smaller than epimastigotes and, most likely, the subpellicular cytoskeleton underneath the posterior portion of the cell body shrink, with the flagellum and kinetoplast remaining fixed. Interestingly, gene knockout of a protein involved in flagellum attachment impairs the appearance of trypomastigotes (Ribeiro de Jesus et al. 1993) and reduces T. cruzi infectivity (Basombrio et al. 2002), suggesting that flagellum attachment could be required for the cellular rearrangements during metacyclogenesis. In conclusion, we have provided evidence that metacyclogenesis involves active cellular reorganization and the next step would be to understand the molecular basis of this cell reorganization.

\section{ACKNOWLEDGMENTS}

We thank Marcia Fujie Araguth for the help in preparing the serial sections and Claudio Rogerio de Oliveira for the help in maintaining the parasite cultures. We also thank Aaron Woolsey for reading and critically reviewing the manuscript. This work was supported by the Fundação de Amparo à Pesquisa do Estado de São Paulo (FAPESP) and Conselho Nacional de Desenvolvimento Científico e Tecnológico (CNPq).

\section{RESUMO}

A diferenciação de formas epimastigotas (proliferativas) do Trypanosoma cruzi, parasita protozoário causador da doença de Chagas, em formas metacíclicas tripomastigotas (infectivas e não proliferativas), pode ser reproduzida em laboratório incubando-se as células em um meio quimicamente definido que imita a urina do inseto vetor deste parasita. Os epimasti- gotas têm um núcleo esférico, o flagelo se projeta da metade do corpo do protozoário e o cinetoplasto (organela que possui o DNA mitocondrial) possui formato de disco. Os tripomastigotas metacíclicos têm um núcleo alongado com o flagelo emergindo da extremidade posterior da célula associado ao cinetoplasto esférico. Neste trabalho descrevemos as mudanças morfológicas que ocorrem durante essa transformação e caracterizamos uma nova forma intermediária do parasita usando reconstrução tridimensional de cortes seriados, visualizados por microscopia eletrônica de transmissão. Essa nova forma intermediária é caracterizada pela compressão do cinetoplasto contra o núcleo alongado, indicando que a metaciclogênese envolve movimentos ativos do cinetoplasto associado à estrutura flagelar em relação ao corpo celular. Como tripomastigotas metacíclicos transcrevem menos que as formas epimastigotas proliferativas, verificamos a presença da RNA polimerase II e medimos a atividade transcricional durante o processo de diferenciação. A presença da enzima e a atividade transcricional permanecem inalteradas durante todas as etapas da metaciclogênese, desaparecendo apenas quando as formas metacíclicas são formadas. Sugerimos que a diferenciação requer uma atividade transcricional, necessária para uma intensa remodelação da célula, que acontece até o cinetoplasto e o flagelo atingirem uma posição posterior do corpo do tripomastigota metacíclico.

Palavras-chave: Trypanosoma cruzi, metaciclogênese, transcrição, RNA polimerase II.

\section{REFERENCES}

Alberio SO, Dias SS, Faria FP, Mortara RA, BarBIERI CL AND FREYMULLER HE. 2004. Ultrastructural and cytochemical identification of megasome in Leishmania (Leishmania) chagasi. Parasitol Res 92: 246-254.

Basombrio MA, Gomez L, Padilla AM, Ciaccio M, NozAKI T AND CROss GA. 2002. Targeted deletion of the gp72 gene decreases the infectivity of Trypanosoma cruzi for mice and insect vectors. J Parasitol 88: 489493.

Bonaldo MC, Souto-Padron T, De Souza W And Goldenberg S. 1988. Cell-substrate adhesion during Trypanosoma cruzi differentiation. J Cell Biol 106: 1349-1358.

Cassola A, de Gaudenzi JG and Frasch AC. 2007. Recruitment of mRNAs to cytoplasmic ribonucleoprotein granules in trypanosomes. Mol Microbiol 65: 655-670. 
Contreras VT, Araujo-Jorge tC, Bonaldo MC, Thomaz N, Barbosa HS, Meirelles MN and GOLDENBERG S. 1988. Biological aspects of the Dm28c clone of Trypanosoma cruzi after metacyclogenesis in chemically defined media. Mem Inst Oswaldo Cruz 83: 123-133.

Cunha-e-Silva, Sant'anna C, Pereira MG, PortoCarreiro I, Jeovanio AL ANd de Souza W. 2006. Reservosomes: multipurpose organelles? Parasitol Res 99: $325-327$.

Dossin FM AND SCHENKMAN S. 2005. Actively transcribing RNA polymerase II concentrates on spliced leader genes in the nucleus of Trypanosoma cruzi. Eukaryot Cell 4: 960-970.

Elias MC, Marques-Porto R, Freymuller E AND SCHENKMAN S. 2001. Transcription rate modulation through the Trypanosoma cruzi life cycle occurs in parallel with changes in nuclear organisation. Mol Biochem Parasitol 112: 79-90.

Elias MC, Da Cunha JP, DE Faria FP, Mortara RA, Freymuller E ANd Schenkman S. 2007. Morphological events during the Trypanosoma cruzi cell cycle. Protist 158: 147-157.

FIALA JC. 2005. Reconstruct: a free editor for serial section microscopy. J Microsc 218: 52-61.

Figueiredo RC, Rosa DS AND SoARES MJ. 2000. Differentiation of Trypanosoma cruzi epimastigotes: metacyclogenesis and adhesion to substrate are triggered by nutritional stress. J Parasitol 86: 1213-1218.

Kollien AH And Schaub GA. 2000. The development of Trypanosoma cruzi in triatominae. Parasitol Today 16 : 381-387.

Krieger MA And Goldenberg S. 1998. Representation of differential expression: a new approach to study differential gene expression in trypanosomatids. Parasitol Today 14: 163-166.

Krieger MA, Avila AR, Ogatta SF, PlazanetMenut C And Goldenberg S. 1999. Differential gene expression during Trypanosoma cruzi metacyclogenesis. Mem Inst Oswaldo Cruz 94: 165-168.
Lustig Y, Sheiner L, VAgima Y, Goldshmidt H, Das A, Bellofatto V and Michaeli S. 2007. Splicedleader RNA silencing: a novel stress-induced mechanism in Trypanosoma brucei. EMBO Rep 8: 408-413.

Parodi-Talice A et AL. 2007. Proteomic analysis of metacyclic trypomastigotes undergoing Trypanosoma cruzi metacyclogenesis. J Mass Spectrom 42: 1422-1432.

Ribeiro de Jesus A, Cooper R, Espinosa M, Gomes JEPL, Garcia ES, Paul S AND Cross GAM. 1993. Gene deletion suggests a role for Trypanosoma cruzi surface glycoprotein GP72 in the insect and mammalian stages of the life cycle. J Cell Sci 106: 1023-1033.

RoUT MP AND FIELD MC. 2001. Isolation and characterization of subnuclear compartments from Trypanosoma brucei. Identification of a major repetitive nuclear lamina component. J Biol Chem 276: 38261-38271.

SanT'AnNA C, DE Souza W and CunHA-E-Silva. 2004. Biogenesis of the reservosomes of Trypanosoma cruzi. Microsc Microanal 10: 637-646.

TEIXEIRA SM. 1998. Control of gene expression in Trypanosomatidae. Braz J Med Biol Res 31: 1503-1516.

Ullu E AND Tschudi C. 1990. Permeable trypanosome cells as a model system for transcription and trans-splicing. Nucleic Acids Res 18: 3319-3326.

Wainszelbaum MJ, BelaunZaran ML, LAMMEL EM, FLORIN-CHRISTENSEN M, FLORIN-CHRISTENSEN J AND ISOLA EL. 2003. Free fatty acids induce cell differentiation to infective forms in Trypanosoma cruzi. Biochem J 375: 705-712.

Yamada-Ogatta SF, Motta MC, Toma HK, Monteiro-Goes V, Avila AR, Muniz BD, NaKamura C, Fragoso SP, Goldenberg S AND Krieger MA. 2004. Trypanosoma cruzi: cloning and characterization of two genes whose expression is up-regulated in metacyclic trypomastigotes. Acta Trop 90: 171-179.

Yoshida N, Blanco SA, Araguth MF, Russo M And GonZALEZ J. 1990. The stage-specific 90-kilodalton surface antigen of metacyclic trypomastigotes of Trypanosoma cruzi. Mol Biochem Parasitol 39: 39-46. 